DOI :

\title{
MEMORY TYPES IN FOREIGN LANGUAGE LEARNING
}

\author{
Rusudan Gogokhia \\ Doctor of Philosophy in Education \\ Associated Professor of European University \\ (Tbilisi, Georgia) \\ e-mail: rusudangogokhia@yahoo.com
}

\begin{abstract}
In foreign language learning the student has to remember the written-text, to understand the listening conversation and renewal it, to do the exercises and remember to include visual, auditory and motor memory in language learning. Learners differ from each other if which memory they have dominant. Learners differ from each other if what modal material they remember easier. The different modes of language learning demand the different loading from the hearing and visual memory. There were two problems to study: 1) To establish the loading type of memory among students, to realize pedagogical principle of individual approach to the students; 2) To compare if there is any genetic dynamics in distribution of memory types according gender. There is experimental study the effect of lexical remembering in B1 level including visual, auditory and motor memoring. There is not any genetic simple line. It is tried to connect the domination of memory type with methodical modes in giving material. We think that our results show whose methodical modes which are used in language learning. In fact, information processing is related to mental processes including memory whose main task is represented in the act of remembering information which is an essential element in successful foreign language learning.
\end{abstract}

Keywords: auditory, visual and motor memory, foreing language learning

\section{ТИПЫ ПАМЯТИ В ОБУЧЕНИИ ИНОСТРАННОМУ ЯЗЫКУ}

\author{
Русудан Гогохия \\ Доктор педагогики, ассоциированный профессор \\ Европейский университет \\ (Тбилиси, Грузия) \\ e-mail: rusudangogokhia@yahoo.com
}

\begin{abstract}
Аннотация. При изучении иностранного языка учащийся должен запоминать письменную речь, понимать устную речь, выполнять упражнения и, при этом, использовать в процессе изучения языка зрительную и слуховую память. Учащиеся отличаются друг от друга тем, какой тип памяти у них доминируют, а также какой изучаемый материал они запоминают легче. Изучение различных языковых единиц требует использования слуховой и зрительной памяти с разной нагрузкой. Для изучения мы выбрали две проблемы: установить какой вид памяти используют студенты, что помогает найти индивидуальный подхода к каждому, сравнить какую роль играет пол при изучении языка, также сравнить если ли генетическая предрасположенность в использовании определенных типов памяти в зависимости от пола учащихся. Данные эксперимента показали какой тип памяти используется для более эффективного запоминания на уровне В1, включая слуховую, зрительную и двигательную память. Есть попытки найти связь между доминирующим типом памяти и методическими приемами при обучении нового материала. Наши исследования показали какие методы используются в процессе использования языка. Фактически, обработка полученной
\end{abstract}


информации связана с психологическими процессами, включая и память, основная задача которой является запоминание информации, которая, в свою очередь, является важнейшим элементом для успешного изучения языка.

Ключевые слова: слуховая, зрительная, двигательная память, изучение языка

\section{INTRODUCTION}

Psychological functions in the process of learning foreign languages: feeling, emotion, imagination, memory, thinking, disability play an important role, and in modern methodology they are somewhat taken into account. One of the most important psychological factors among them is memory in its active (conscious) or passive (unconscious) forms, as it is directly related to the learning process and plays an important role in its effective management. Memory is associated with the cognitive processes that are one of the most persistent in terms of volume of research. There are many classifications of memory, different types are separated and factors affecting them are studied, but these parameters are not specific to foreign language acquisition. The memory functions involved in this process are not fully defined and the factors that influence the relationship between memory and foreign language acquisition are not clearly identified.

In the process of learning a foreign language, the learner has to remember written text, understand and rehearse conversations, do exercises and remember them. So to engage visual, auditory and motor memory in language learning. Learners differ from each other in terms of which type of memory is dominant.

It is known from observations that some make it easier to remember visual material, some acoustic and some motor. This is also shown how each given material is studied orally: some prefer silent reading (optical type), some prefer when they are read, and at the same time develop in his/her mind memorize material with some movement (for example, recording motion) in memory (motor type) and whether it depends on the methodological teaching methods.

These types are seldom found in pure form, and they are almost exclusively among creative artists - namely, a purely optical type artist, acoustic - musician and motor - dancer. Among ordinary people, however, there is usually a mixed kind of learners, but when one of the senses is involved. We are still allowed to talk about the matching type. For example, if a learner has a better visual impression of a person, and therefore he/she prefers this material, we have the complete right to refer such learner to a visual type.

As second language learning is concerned, students often complain that they have bad memories. From recognition memory perspective, they have bad memory habits which can be the reason for poor recall (Vallar and Papagno 2002). Memory strategies are based on simple principles like laying things out in order, making association, and reviewing. These principles are employed when a learner faces challenge of vocabulary learning. The words and phrases can be associated with visual images that can be stored and retrieved for communication. Many learners make use of visual images, but some find it easy to connect words and phrases with sound, motion or touch (Oxford 2001).

Namely, it has long been traditionally accepted under this sign to allocate three types of memory: depending on whether one is better remembered by sight, hearing, or kinesthetically. They choose memory-based on vision - optical, auditory - acoustic and motor type. 
The first type of learner memory is characterized not only by better comprehension of optical perception, but also by the dominance of optical performances in memory and thought processes. The second characteristic is not only better comprehension of hearing but also dominance of auditory performances.

If two types of learners are faced with the task of remembering a foreign word, one will recall its spelling form and the other with its audible icon, sound. Third, the learner with the motor type is particularly well-remembered for the material in which the perception of kinesthetic sensations is involved - one's own movement, motor habit, exercise, dance, etc. And reading or listening to content is especially well-remembered if their perception is related to his or her own movements: for example, when he/she writes memorable material or, while reading and listening to it himself/herself, even the audiovisual, the speech organs are properly motivated to speak those words. Memory role in language learning has long been of interest to researchers in first and second language acquisition. It tries to elicit the relationship between human memory and foreign language learners' performance through the study of the case of first year EFL university students using a test as a research instrument.

The compression ratio increases significantly: a) by increasing the level of language proficiency, the level of language proficiency is determined by the amount of long and short memory; b) task understanding, activation of working memory; c) by structuring the material; d) by incorporating the factor of interest.

Consider which block of memory is involved in intellectual activity: If the memory block contains only direct memory, then the result will be relatively low; If working with memory is also included, then we get a better result; And if in conjunction with short-lived and working-memory, prior knowledge of the long-term memory is activated in advance, recovery of previous experience, and understanding of this experience-analyzing the intended purpose, then we expect the best results.

Intellectual activity is the determinant of remembering efficiency in any intended teacher. This means that the effectiveness of remembering will be higher in all settings when the individual activity of the subject is high and therefore the level of comprehension of the given material, which in turn will lead to the teacher's correct remembering strategies.

The amount of memory in a foreign language is not a constant indicator - it is subject to many factors, e.g. Level of language proficiency, structuring, interest. The interest rate on a given assignment has a certain effect on the retention ratio if the latter is due to certain factors. In high school, in order to gain profound knowledge of foreign languages, we consider it necessary to take into account a special profile based on the most up-to-date memory-based memory factor.

\section{LITERATURE REVIEW}

Research as a cognitive process of memory has attracted the attention of scientists since ancient times. In ancient times, philosophers (Plato, Aristotle, etc.) were keenly interested in the processes by which human knowledge is acquired. They were well aware that learning is the direct way to acquire knowledge, and memorization is the means by which knowledge is maintained.

In the second half of the nineteenth century and in the early twentieth century, scientists such as Wilhelm Wundt (volume of attention, method of introspection) made significant contributions to memory research; Edward Titchener (structuralism, introspection method); Hermann Ebinghouse 
(associationism, memory regularities and classical methods); William James (Functionalism, Primary and Secondary Memory) (D. Parjanadze 2008).

In the 1930s, the theory of Reconstructionism was founded in the psychology of memory by the English scientist Frederick Bartlett. In his view, memory plays a crucial role in memory. He held that the memory processes and processes the perceived events in memory, that is, their reconstruction, which is not a mechanical repetition of any event. This is where the active process of information processing takes place. Bartlett uses the content of everyday life in his experiments and introduces the principle of ecological validity and method of scheme in psychology (Bartlett 1932).

At a general level, memory processing tends to involve the way L2 learners take in, restore and retrieve information. This means that educators and language instructors need to consider how best to present information and how to maximize opportunities to ensure meaningful links are made to aid later retrieval of information. These considerations and opportunities can be planned within general classroom management and teaching (Miyake et al., 2017).

It is very important to remember what kind of sensory material the learner has to remember, what modality sensors are involved in the working process. The memory of most modern humans is relatively more effective in visual material (most people, for example, remember their eyes more read than they hear). But in the main, the advantages of some modality in the process of remembering depend on the individual, typological features of humans.

A study of the evolution of auditory hearing and kinesthetic shows that under certain conditions of life and activity, the optimality of these functions experience a certain load and shift to a later period of life. After that they are stabilized and confronted with evolutionary processes.

These provisions need to be understood in the sense that visual and auditory memory can be more or less activated at different ages depending on what activity a learner engages in. Different ways of learning a language require different levels of auditory and visual memory. Therefore, we decided to look for the leading form of memory among B1 students.

\section{RESEARCH METHOD}

All experiments were a person of English language training courses (level: B1), which represents an intermediate step to the average level (Intermediate Level).

Our study faced two tasks: 1) to identify the leading type of memory in order to implement the pedagogical principle of individual approach to students; 2) compare if there any gender dynamics in the distribution of memory types.

The tests were conducted on 100 students. The learners listened to each word that was presented aurally, and then performed three tasks: 1) learners had to repeat each word aloud, 2) learners had to indicate whether each noun referred to a living or non-living thing. After the test learners were probed to determine whether they were aware of the animacy relationship during the study. Data from the learners who did not demonstrate awareness indicated a performance significantly better than chance on the generalization test. We were interested in the effect of language competence on the retention ratio. We hypothesized that this knowledge, along with immediate memory, would involve working memory and stimulate the recall process by incorporating psychological factors such as language proficiency, structure, and interest. We hypothesized that the test would incorporate cache memory and activate the cached working memory in a shorter memory block, which is responsible for the retention and processing of 
information and is a transitional stage in decision making. At the same time, it would increase students' ability to use the material more widely and speed up the search process.

Figure 01 Results and discussions

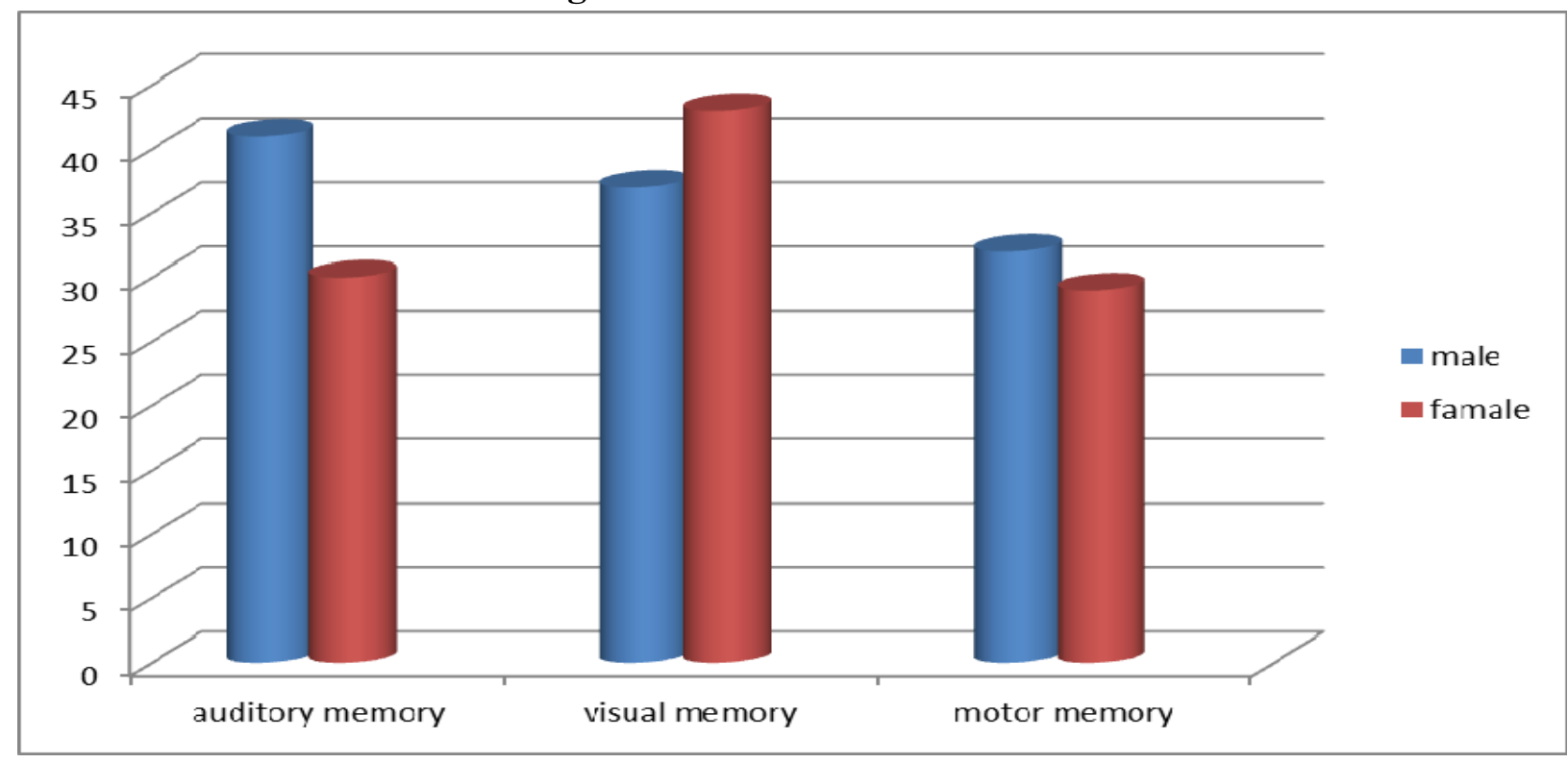

The distribution of memory types is not varied. As shown in the table, there is no significant difference between female and male. However, male are more often associated with mixed memory and they have more auditory memory than others. According the results female have visual memory.

These studies suggest a variety of productive ways of encouraging students to engage their knowledge and experience prior to reading and that in nearly all cases, the impact on story understanding is positive, at least for narrative texts in which themes and topics are likely to be highly familiar. The beatings continued their intensive study of the English language, which to some extent increased their prior knowledge, which was associated with an increase in the amount of long memory storage.

In pursuit of committing L2 learned material to memory, many comparisons of instructional methodologies suggest that having learners take an active role in constructing a network of meaning for a word is critical. Making word meanings and relationships visible is another way to involve students actively in constructing word meaning semantic webs, maps, organizers, or other relational charts not only graphically display attributes of meanings, but provide a memory organizer for later use (McCarville, 2000).

The results allow us to recommend high school foreign language teachers to help them maximize students' prior knowledge in order to stimulate the learning process, which in turn will increase the retention ratio.

\section{CONCLUSION}

Learners differ from each other in terms of which modalities are easier to remember. The paper experimentally examines the effectiveness of remembering foreign vocabulary in terms of visual, auditory, and motor memory. It is common to associate the dominant type of memory with the methodical means of delivering the material. We think that the results in some way reflect the 
methodological tools used in language teaching. Students do not yet have the type of memory that is permanently formed and depends on the type of learning material provided.

It clear that sensory material was also important in that, for example, in order to memorize verbal material, it is only optical or acoustic to deliver this material simultaneously. As for each of these separately, the form of acoustic delivery has proved to be more favorable than that of optics alone, in the case of other types of optical subject. This fact also indicates that one may belong to one particular type of material, and another to another material: one may memorize geometric figures better, but words more acoustically. The material is very important.

Thus, according to the results of the experiment, the direct memory in a foreign language has a smaller amount of initial level of foreign language learning (Level: Beginner). This finding allows us to make a recommendation to high school foreign language teachers, that it is desirable to reinforce foreign language learning at the elementary level by means of appropriate equivalents in their native language in order to more easily overcome the barrier. To maximize students' prior knowledge in order to stimulate the learning process, this in turn will increase the retention ratio. Increasing the memory coefficient was determined by the incorporation of the executive memory system of working memory in addition to direct memory, which defined higher levels of learning, goals and objectives.

However, individual difference is very important. The teacher should know which way is appropriate for the student's natural individual characteristics and to consider them in the teaching process. Memory test results would have a significant impact on both the material's structure and on the cognitive processes involved in memory, which in turn are conditioned by the presence of other psychological factors. The interest rate on a given task is affected by the recall coefficient if the latter is driven by certain factors, such as the ability to express one, the ability to compete with others; prior knowledge and analysis of recall mechanisms; Predicting the purpose; Preliminary analysis of the task.

All of this enhances the concentration of attention, which ultimately results in better results. Intellectual activity is the determinant of remembering efficiency in any intended teacher. This means that the effectiveness of remembering in all settings (e. g, speed, accuracy, robustness, etc.) will be higher when the subject's individual activity is high and therefore the level of comprehension of the material, which in turn is determined by the teacher use correct strategies. Learning new vocabulary and grammatical structures should take into account mnemonic processes; Sort the material on the same topic in order of complexity to make it easier to remember, repeat, and reinforce the material.

When teaching a foreign language in high school, the methodology of teaching should be based on the basics of metamorphosis, that is, knowledge of one's own memory, remembering strategies, and aids.

\section{LIST OF REFERENCES}

Parjanadze, D. (2008). „Mkhsierebis psikologia“ sh.p'.sh. 'Tata Solushnebsis“ mier, Tbilisi.

Bui, D. C., \& Myerson, J. (2014). The role of working memory abilities in lecture note-taking. Learning and Individual Differences, 33, 12-22. 
Frank, D. J., Nara, B., Zavagnin, M., Touron, D. R., \& Kane, M. J. (2015). Validating older adults' reports of less mind-wandering: An examination of eye movements and dispositional influences. Psychology and Aging, 30, 266-278.

Miyake A., (2017). Working memory constraints in comprehension: evidence from individual differences, aphasia, and aging. A. Gernsbacher- Morton (Ed.), Handbook of Psycholinguistics, Academic Publishers, San Diego, pp. 1075-1122

McCarville, (2000). K.B. McCarville. Keyword mnemonic and vocabulary acquisition for developmental college students. Journal of Developmental Education, 16 (2000), pp. 2-4

Oxford, R., (2001). Research on language learning strategies: Purpose, Methods, Issues. Presentation, Hokkaido University.

Randall, J. G., Oswald, F. L., \& Beier, M. E. (2014). Mind-wandering, cognition, and performance: A theory-driven meta-analysis of attention regulation. Psychological Bulletin, 140, 1411-1431.

Vallar and Papagno, (2002). G. Vallar, C. Papagno. Neuropsychological impairments of verbal short-term memory. The Handbook of Memory Disorders, 2 (2002), pp. 249-270

\section{For citation:}

Gogokhia, R. (2020) Memory Types in Foreign Language Learning. International ScientificPedagogical Organization of Philologists “WEST-EAST” (ISPOP). Scientific Journal WESTEAST. Vol 3 N1 (March, 2020). pp. 11-16. doi:

\section{Для цитирования:}

Гогохия, Р. (2020) Типы памяти в обучении иностранному языку // International ScientificPedagogical Organization of Philologists “WEST-EAST" (ISPOP). Scientific Journal WESTEAST. Vol 3N1 (March, 2020). C. 11-16. doi:

Information about the author: Rusudan Gogokhia - Doctor of Philosophy in Education, Associated Professor of European University (Georgia).

E-mail: rusudangogokhia@yahoo.com

Сведения об авторе: Русудан Гогохия - доктор педагогики, ассоциированный профессор, Европейский университет (Грузия)

E-mail: rusudangogokhia@yahoo.com

Manuscript received: $12 / 05 / 2019$

Accepted for publication: $01 / 15 / 2020$

Рукопись получена: 12/05/2019

Принята к печати: 01/15/2020 